\title{
Jesus Christ, Glory and Cognition. Is Eph 1:15-23 a Judaistic and/or Hellenistic Christian Text?
}

\author{
WALDEMAR LINKE \\ Cardinal Stefan Wyszynski University in Warsaw \\ waldemarlinke@gmail.com, ORCID: 0000-0001-9800-5341
}

\begin{abstract}
The paper is an interpretation of Eph 1:15-23 which is a consequence of the shorter version

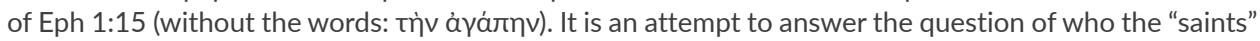
are in this verse and the entire pericope, what background (Hellenistic or Judaic) this concept has, and what was the character of the church community in this city in the post-Pauline period. The method used in this paper consists of historical and contextual analysis of lexicographical end ideological material used in the pericope. The first step is a study of the rhetorical structure of Eph as the instrument for interpretation of the role of the pericope in the meaning of the text. The second part of the paper is presented the binary way of exposition: in the language of Judaism and in the Hellenistic terms. From this perspective the category of "saints" is described. From this analysis it is concluded: "saints" are the group belonging to the Judeo-Christian component of the Church, the political substructure of the Church but not in terms of the separation, but of the pluralistic unity.
\end{abstract}

Keywords: Jesus Christ, glory, knowledge, saints, Hellenism, Judaism, Eph 1:15-23

In the exegetical studies on Eph 1:15, the problem of textual criticism, even if noted by commentators, is usually overlooked. It consists in the lack of the words $\tau$ inv

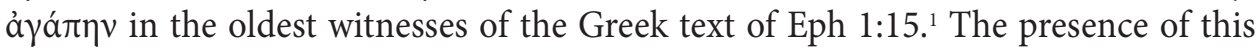
noun and article is crucial not only for the understanding of this verse alone but also of the pericope Eph 1:15-23 and many motifs in the rest of this Deutero-Pauline letter. Above all, it is referred to the character of Christian community and its burning issues of the relation between those who came to faith through Judaism and those whose way was different. The nature of the relation between those two groups pertains to the depiction of Jesus Christ and Salvation accomplished through Him. Hence, a study of the state of Eph 1:15 and the status of "the saints" (political relations within Christian community) the verse speaks about, are considered premises for the theological conclusions: Christological and soteriological ones.

Lionel J. Windsor presented a hypothesis of the attribution of Eph to the middle stage of formation of the relations between Christian milieu and Judaism (the turn of

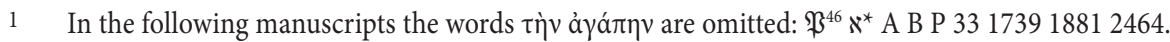


$1^{\text {st }}$ and $2^{\text {nd }}$ century). At that time, the problem of Christian-Jewish relations is an internal matter for the Christian community, the problem which seeks its depiction. Christian community is looking for an identity build upon the identity of Israel, both ethnical and religious. In the $2^{\text {nd }}$ century, the solution to this problem will assume that from the ethnic perspective Christians are a "third race," between gentiles (Greeks) and Jews, that inherits theological and soteriological prerogatives of Israel and replaces it. ${ }^{2}$ Windsor entered here in a polemic with Andrew T. Lincoln, who perceives the traces of self-definition of the Church as the new Israel - "third race" - already in Eph. ${ }^{3}$ He sees Frederick F. Bruce ${ }^{4}$ or Marcus Barth ${ }^{5}$ as his predecessors. After him, Benjamin H. Dunning, ${ }^{6}$ Charles H. Talbert ${ }^{7}$ or Minna Shkul ${ }^{8}$ will reproduce this line of thought. Windsor himself perceives Eph rather as a continuation of the theology of Christian-Jewish relations present in St. Paul, e.g., in the Letter to the Romans, than a fundament of the theology of replacement of Israel by the Christian "nation." Thus, in this article we will undertake the task of answering the question of the state of Christian-Jewish relation in Eph and its impact on the faith of Christians themselves from a new perspective.

\section{The Place of Eph 1:15-23 in the Letter and the Internal Structure of the Pericope}

The recognition of shorter text as the fundament for an interpretation puts the in-

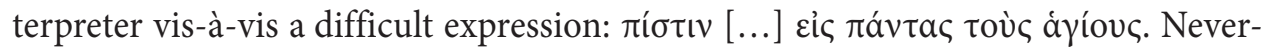
theless, regarding the textual-critical arguments given ${ }^{10}$ the analysis of the shorter version presents itself as an exegetical necessity. The interpretation needs to consider the context of this utterance: above all the closest (Eph 1:15-23) and the broader (Eph 1:3-2:10) context.

In his comprehensive study of the rhetorical structure of Eph, Roman Mazur ${ }^{11}$ adopted an opinion that Eph 2:2-6:2 forms a corpus of Eph, where Eph 1:1-23 would be the complex introduction and Eph 6:21-23 the simple ending of the letter. He divided the introductory part into epistolary prescript (1:1-2), rhetorical exordium

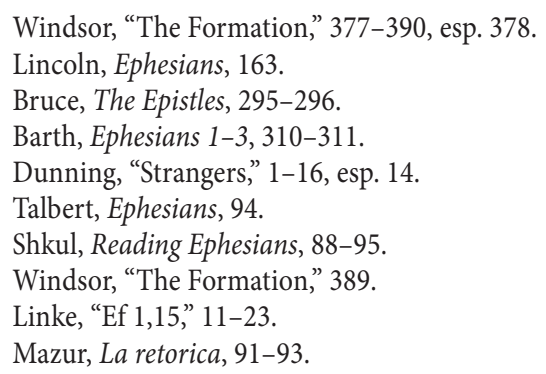


(1:3-14), and thanksgiving (1:15-23) which he describes as "uno schema quasi commune" in Pauline letters. ${ }^{12}$ This scholar classifies Eph 1:15-23 as amplification of exordium. ${ }^{13}$ A similar confusion is characteristic for Andrew T. Lincoln's commentary, where the epistolary and rhetorical structure of the fragment is described as intercessory (thanksgiving and prayer), thus focusing on its content, not its function. ${ }^{14} \mathrm{Lin}$ coln seems to follow the solution of Ernst Käsemann, who marks a division between Eph 1:23 and 2:1 into the introductory (Christological) and central (ecclesiological) parts $(2: 1-3: 21) .{ }^{15}$ It is a solution that deviates from the exegetical tradition initiated already with Johann A. Bengel's remark that Eph 1:3-14 constitutes a compendium of Gospel doctrine, expressed in the way of pathos, encompassing the first part of the letter: Eph 1:3-3:21, after which comes an exhortation - 4:1-6:22. ${ }^{16}$ Those assumptions became vital and are still supported by exegetes in the $20^{\text {th }}$ century. ${ }^{17}$ A privileged position of Eph 1:3-14 as a programmatic text and a hermeneutical clue for the exegesis of the whole $\mathrm{Eph}^{18}$ provided a fundament for compositional schemes of the letter that points out to Eph 1:15 as the beginning of epistolary corpus. ${ }^{19} \mathrm{~A}$ new and creative solution has been put forward by Rudolf Schnackenburg, ${ }^{20}$ who moved the beginning of the introductory part to Eph 2:11.

On this background, the solutions of Käsemann and Mazur seems to have the advantage of exposing the introductory character of Eph $1 .{ }^{21}$ The refined and well-grounded proposition of Mazur fails to find a binding material for Eph 1:15-23. Hence, he divides the fragment into virtually independent parts: thanksgiving (1:15-16), intercessory prayer (1:17-19) and God's action in Christ (1:20-23). This solution is close to the one proposed by Peter O'Brien. ${ }^{22}$ O'Brien does not offer such a detailed analysis of the epistolary and rhetorical structure of Eph as Mazur, he does, however, preserve a comprehensive vision of Eph 1:15-23. The approach we would like to propose for the interpretation of Eph 1:15-23 is based on what bonds this complex, nevertheless coherent text.

Eph 1:3-14 is a prayer of benediction (eulogia or brākāh), which can find its place in the Second Temple Judaism. ${ }^{23}$ Though it had a very long history in religion or magic, in rabbinic Judaism, we can speak of an utterly different scale of its

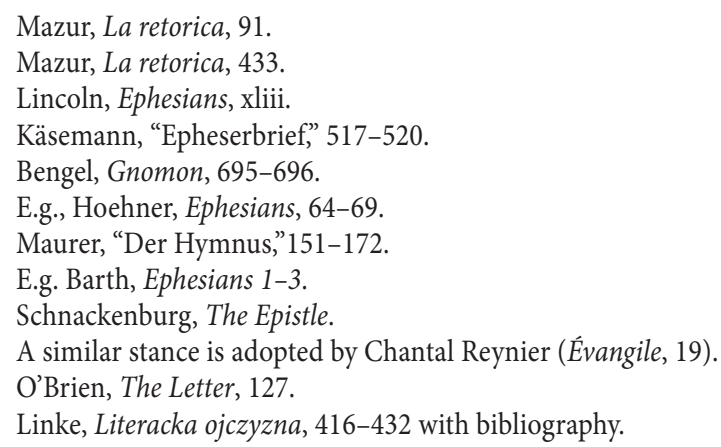


presence, when the prayer of benediction became common and mandatory practice (b. Ber. 35a). The ground for this situation has been prepared by the form of religiosity present, for instance, in the Book of Tobit. Already Hermann W. Beyer noticed: "The concept of 'benediction' plays a surprisingly meagre role in the classical world. There is no specific terminology for it." ${ }^{24}$ It derives from Near Eastern culture and its presence in the New Testament indicates connections with Jewish milieu. Yet, one has to remember the specificity and frequency of the use of the term eulogia in Eph 1:3.

Michael Theobald, while comparing Eph with the Epistle to the Colossians, indicates the originality of the composition of Eph (in a way contra his other thesis, where he considers Col as pre-text for Eph). ${ }^{25}$ While both letters include common elements for this form of expression - prescript (Eph 1:1-2; Col 1:1-2) and thanksgiving with intercessory prayer (Eph 1:15-23; Col 1:3-14) - Eph embodies a very long thanksgiving (1:3-14) and an analysis of the dynamical situation of the recipients, who experienced turnarounds: towards salvation (2:1-10) and towards unity through Christ (2:11-13). Those original elements of Eph produce a peculiar context for the elements recognised as mutual for both texts representing post-Pauline tradition. Eulogia from Eph 1:3-14 precedes thanksgiving but do not substitute it. ${ }^{26}$ It has its own function, complementary to those of thanksgiving. On this basis, O'Brien infers that Eph equates conflicted - or at least not entirely consentient - Jewish and Gentile milieus ( $(\varepsilon \chi \theta \rho \eta$ in Eph 2:14.16), and that thanksgiving constitute a tribute towards the latter. His argumentation is worth noticing. Nevertheless, it should be considered whether it explains in a sufficient way the complicated situation of Eph 1, which introduces in a vision of resolving the conflict between Judaeo-Christians and Gentile-Christians, described in Eph. It is even more important in the context of Charles H. Talbert's study, in which he tries to demonstrate that the sequence benediction-thanksgiving-intercessory prayer has its Judaistic precedent in Jub. 22:6-9, and more often a different succession of elements is used: benediction-intercessory prayer (cf. Tob 3:11.12-15; 8:5-6.7; 1 Macc 4:30.31-33) or benediction-thanksgiving (cf. Dan 2:20-22.23, 1Esd 4:60a.60b). ${ }^{27}$

A remark regarding Talbert's reasoning should be made here. Due to a great difference in purpose of the Judaistic texts he considers as a reference and Eph 1:3-23, the independence of the benediction in Eph 1:3-14 is noticeable and has to be treated in a different way than short prayer passages quoted by Talbert. In effect, the break in consistency after Eph 1:19 and creation of entity Eph 1:20-2:10 proposed by Talbert is based rather on external analogies than on the study of Eph 1:3-2:10. ${ }^{28}$

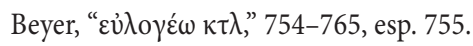

Theobald, "La Lettera," 507-527, esp. 515-516.

O'Brien, The Letter, 124.

Talbert, Ephesians, 53.

Talbert, Ephesians, 55.
} 
On the one hand, an important argument in favour of the Semitic character of Eph 1:3-14 benediction is the use of the preposition $\dot{\varepsilon} v$. Two of the three uses of this preposition in Eph 1:3 are instrumental, therefore are considered as semitisms. At the same time, however, it should be taken into account that in this specifically Judaistic element - the blessing - some of elements are not consistent with this cultural background. Whereas in Judaism, a benediction usually concerned specific and

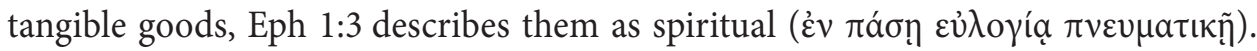
"In the OT, the benefits were primarily material, such as prosperity and physical pro-

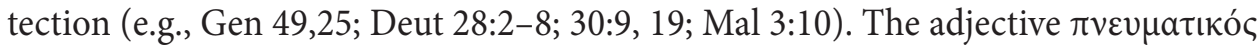
in classical Greek refers to wind, air, and breath and is not used in the LXX."29 In this way, a specific Judaistic element receives in this text some characteristics, that show a new meaning of Judaistic terminology, rooted in extra-Jewish context.

On the other hand, we can perceive Eph 1:15-23 as a typical thanksgiving in the light of the examples from Corpus Paulinum. They function as an opening element for the epistolary corpus, after prescript. ${ }^{30}$ Already Peter T. O'Brien noticed, concerning Eph 1:15ff, that a thanksgiving prayer as the beginning of Eph corpus is characteristic for Hellenistic Judaism. As an example, he quotes 2 Macc 1:10-13 - the thanksgiving from a long letter of Judah Maccabee and Gerousia of Jerusalem to Aristoboulos of

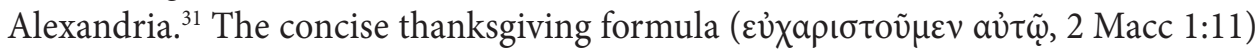
is followed by a relatively long, fictional (Antiochus III the Great has been confused with Antiochus IV Epiphanes) and stylistically complicated narration, which justifies the thanksgiving itself (vv. 13-17). It ends with a benediction (v. 17). The corpus of the letter (2 Macc 2:1-18) concerns a newly established feast of rededication of the Temple. Judeans encourage Alexandrian Jews to celebrate it. The formal epistolary ending is missing, ${ }^{32}$ what should be noted along with the quasi-official character of the greeting, characteristic rather for private letters. ${ }^{33}$ This text (it is insignificant whether a document or literary form) is an illustration of letter-writing practice in the milieu of Hellenised Jews in the $2^{\text {nd }}$ century BCE. The example suggests a loose connection between thanksgiving and corpus. Referring to Eph, it could signify that 1:3-23 divided on benediction (vv. 3-14) and thanksgiving (vv. 15-23) constitute an autonomous part of the letter, loosely connected with the corpus. This kind of practice differs considerably from what Peter Arzt-Grabner described in the cited article as Paul's own practice. ${ }^{34}$

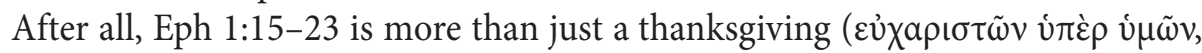
Eph 1:16). The pericope also embodies related formulas: report of prayer ( $\dot{\varepsilon} \pi \mathrm{i} \tau \tilde{\omega} v$

\footnotetext{
29 Hoehner, Ephesians, 167.

30 Arzt-Grabner, "Paul's Letter," 129-158, esp. 151.

31 O'Brien, The Letter, 124, n. 142.

32 Gryglewicz, Księgi Machabejskie, 274.

33 Laskowski, Druga Księga Machabejska, 130.

34 Arzt-Grabner, "Paul's Letter," 151.
} 


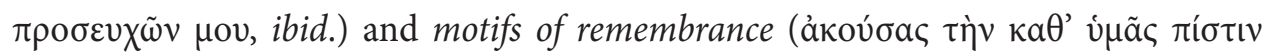

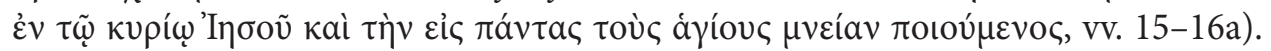
All those elements are concentrated in vv. 15-16. Hence, there were attempts to divide this semantical entity into smaller sections. ${ }^{35}$ The analogy with 2 Macc 1:10-17 proves that narration or another justification of the thanksgiving is an integral component of an entity in which this kind of prayer constitutes a decisive element. Thus, Eph 1:17-23 relates to the expressions conceptualised (vv. 15-16) in the same way as the story of Antiochus' death (2 Macc 1:13-16) to the thanksgiving for the events described in 2 Macc 1:12 in a very ambiguous way. Pursuing this thought, it must be stated that 2 Macc 1:17 corresponds to Eph 1:3-14.

Eph 1:15, just like 2 Macc 1:12, is a narrative text, though of another character than the letter of Judah to Aristoboulos. The main event that occurs in Eph 1:15 is the act of hearing of Paul (understood as a literary character, without the implication

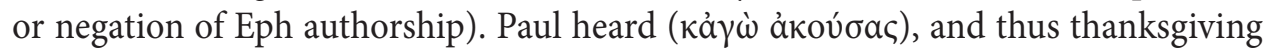
and prayer (v. 16) are the effects of this hearing. We deal here with a sequence of events, where the protagonist is also the narrator. Eph 1:17-19 encompasses an utterance related closely to the reassurance of incessant prayer, as it describes the content of the prayer. The narration relating to a different subject than Paul, is to be found in Eph 1:20-23, where we read a kerygmatic story about the deeds of God the Father concerning His Son, through His resurrection and exaltation. The element of intercessory prayer in Eph 1:15-19 is the prevalent element. It is lacking in 2 Macc 1:11-12, what is compensated by the development of the gratitude motif towards God.

What was said about the rhetorical function of the pericope Eph 1:15-23, its place in the structure of Eph and analogies with 2 Macc 1:10-2:18, show the text as exceptional not due to its content, but its function. Since Eph 1:15 is a compositional equivalent of 2 Macc 1:11a.11c-12, now it has to be read in its determined (shorter) version, and its relation to Eph 1:15-23 has to be described.

\section{A Binary Mode of Thinking in Eph 1:15 and the Relation of Judaism and Hellenism in Eph 1:15-23}

Since the notable study of James Barr on linguistic research concerning the terms 'faith' and 'truth' in the Bible. ${ }^{36}$ it is not possible to adopt a two-way understanding of

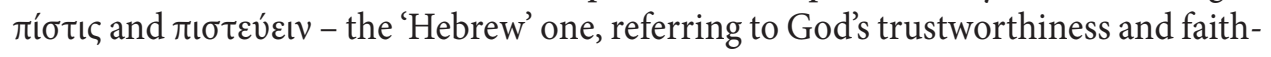

35 O'Brien, The Letter, 127; Mazur, La retorica, 81.

$367^{\text {th }}$ chapter in: Barr, The Semantics of Biblical Language, cited after Italian translation: Semantica del linguaggio biblico, 229-286. 
fulness, and the 'Greek' one, where the metaphysical sense, based upon considering something as true and thus credible, is predominant. According to Barr, especially the Pauline use of this terminology does not allow any distinction between Semitic and Greek motifs in the language and thought of Paul and other New Testament authors. In this sense, we can read in them as an example of Hellenistic character of Early Christian message or, in the theological language, Christian revelation. Different uses, previously attributed to different languages and types of thought, are mixed together, or rather complement each other, to produce qualitatively new statements, that allowed the formation of the New Testament. If we adopt, after Barr, that 'a writer such as Paul' had at his disposal a very broad and ununiform term, there is no need to refrain from assuming that he made use of all its semantic possibilities. ${ }^{37}$ Groups of Hellenised Jews acquired to a different degree the traditions of their ethnoreligious group and those from their local context. The reactions to innovative approach to traditions of Judaism, promulgated by Christians, were not homogeneous as well. This also applies to small groups incorporated in greater social structures and particular entities. The symphonic character of traditions and semantic innovations brought forth by its (dis)harmonies, constitute one of the most important traits of Hellenistic culture, including Early Christian one. From this perspective, we should consider the problem of Eph 1:15.

The 'retrieval' of the shorter version of Eph 1:15 establishes a need to read two grammatical constructs with accusative: the first is developed by $\dot{\varepsilon} v+$ instrumental

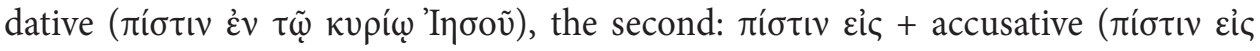

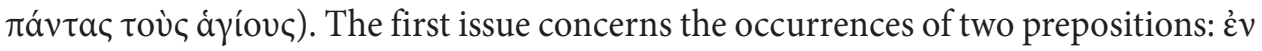
and $\varepsilon i c$. It is problematic from the point of view of classical philology because the verb $\pi\llcorner\sigma \tau \varepsilon \dot{\omega} \omega$ and the noun $\pi i ́ \sigma \tau \iota \varsigma$ are connected with nouns without prepositions (with dative). In Hellenistic Greek, we can observe phenomena affecting the change in this situation: a recourse of dative and occupancy of new spaces by some of the prepositions, including $\dot{\varepsilon} v$ and $\varepsilon i \varsigma(\$ 203) .{ }^{38}$ Often, $\varepsilon i \varsigma$ also takes the place of a usual dative $(\$ 207,1) .{ }^{39}$ Concerning the verb $\pi ı \sigma \tau \varepsilon v \varepsilon \varepsilon v$, we can speak about the oscillation between the use of $\dot{\varepsilon} v$ and $\varepsilon \dot{\varepsilon} \zeta$ in the instrumental sense $(\$ 206,2)$, but it is demonstrated that $\varepsilon \grave{\varepsilon} \zeta$ is rather the equivalent of if in words based on the stem wמן we can perceive the main equivalent for the words from the family $\pi ı \sigma \tau-$, in $\pi i \sigma \tau \imath v \dot{\varepsilon} v$ we can see the equivalent of אמן ?

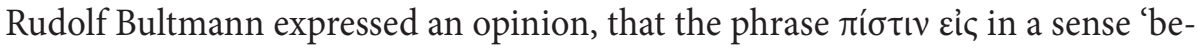
lieve in' does not have an analogy in Greek, even in the Septuagint, except for the er-

\footnotetext{
Barr, Semantica del linguaggio biblico, 282-283.

Blass - Debrunner, Grammatica, 276.

Blass - Debrunner, Grammatica, 279.

Blass - Debrunner, Grammatica, 278.
} 
roneous translation of Sir 38:31. ${ }^{41}$ He refers to a comprehensive article on عic by

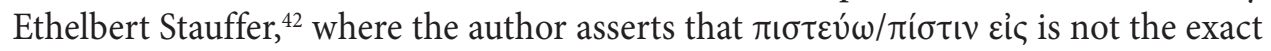
equivalent of the expression האמֶמין due to the fact that Hebrew expression relates to the issue of trust in human relations, whereas the Greek one, characteristic for the New Testament, relates to faith in Jesus Christ as Lord.

Examples of constructs of the family אמן with? can be found, e.g., in Exod 4:1.8-9. In the Septuagint all the constructs with $?$ are translated as Greek nonprepositional constructs with dative, whereas the construct with nonprepositionally with the genitive. This translation practice is based on the principle of respecting the syntactical rules of destined language, Greek in this case. This situation differs from the temporal use of the preposition $?$ in the expression

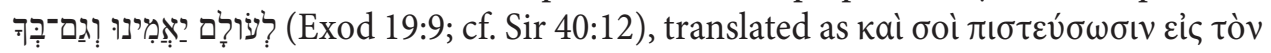

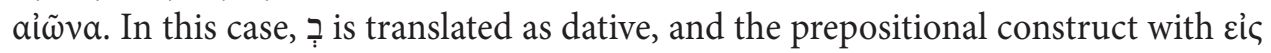
corresponds to ??. The last example from the Pentateuch comes from Gen 45:26. It

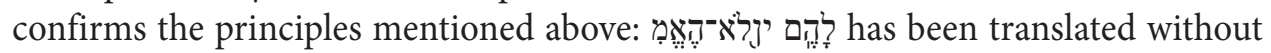

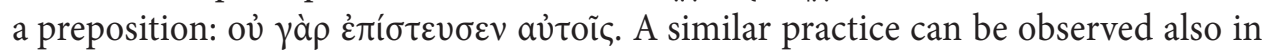

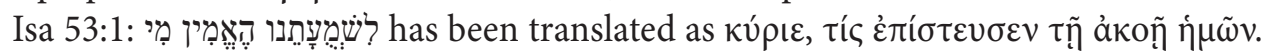
The example is interesting because it illustrates the situation in which not the person but a sort of an object - what has been heard - is the complement of the verb describing the act of accepting with trust, with faith.

The Septuagint material can be confronted with the known and ample literary

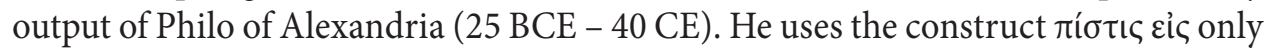
two times: in De aeternitate mundi (Aet. 1,52) and in Quis rerum divinarum heres sit (Her. 1,94). The first fragment shows that the spoken language could have known

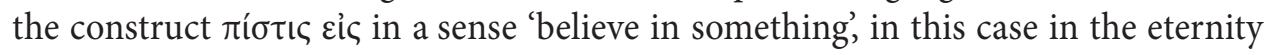
of the world - a thesis examined by Philo in dialogue with philosophical thought of Plato. It is an argument contra the ascertainment of Bultmann, and thus worth noticing. The passus from Quis rerum divinarum heres sit, where Philo points to Gen 15:6 and comments on this verse, seems to be more of importance here. The author discusses the first part of Gen 15:6 in Her. 1,90 and quotes verbatim the Septuagint. While commenting on the second part, Philo paraphrases the verse. This paraphrase seems to be intentional, as he is not referring directly to the Scripture, as is conveyed by Francis H. Colson's and George H. Whitaker's translations (otherwise

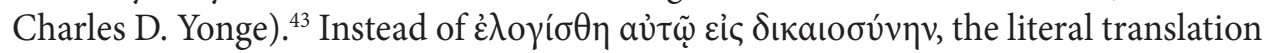

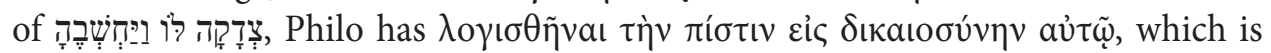
distinctly different from the biblical text. The comment of the Alexandrian scholar to the text explains his proceedings. It is a construct that, on the one hand, respects

\footnotetext{
Bultmann - Weiser, " $\pi$ $1 \tau \tau \varepsilon v ́ \omega \kappa \tau \lambda$," 174-228, esp. 203 and n. 220.

Stauffer, "Eic," 420-442, esp. 432.

Philo, Philo, 329.
} 
Hebrew syntax (as in the Septuagint), on the other hand, Philo manipulates the text to emphasise faith in one God as the source of righteousness. However, the expression does not signify 'faith in righteousness', and as such does not enter the field of our speculations (though the verbal construct is not present in Philo).

The set of examples from the Septuagint is not exhaustive. Nevertheless, it can be considered representative. The examples mentioned do not distinguish in the original, nor in the translation, the meaning of the expression אמן from the object (complement) of the verb. It always signifies trust in the content of the communication being transmitted and, hence, to the communicating. The Septuagint discloses - with

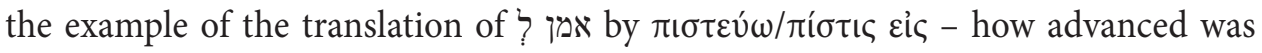
the process of cultural Hellenization of Jewish communities in Alexandria. The analysis of Philo's texts confirms this conclusion..$^{44}$ It is not revelatory to state that higher and better educated social strata of Alexandria used the Greek language correctly. But this statement entrail another one, that can be missed at times by scholars. Separate syntactical categories of Hebrew, merged in the thinking of Hellenised Jews, thus contributing to the creation of a new conceptual grid. The diaspora spoke with the language different from Hebrew not only in the sense of a separate dictionary but in a much more profound sense: the diaspora described the world in different categories, that should be considered Hellenistic in the sense of drawing upon Greek linguistic culture, what has its philosophical and theological consequences. The language of the Alexandrian diaspora depicts Jews, who aspired to be Greeks believing in One God.

The New Testament is very ununiform when it comes to the distribution of $49 \mathrm{oc}-$

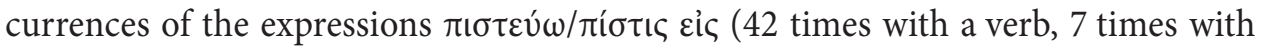
a noun). Though the form with a verb is much more common, it is not present in Mark (except for lectio varia in Mark 9:42), nor in Luke, and occurs only once in Matt (18:6). Acts employs the form with a verb in 4 instances (10:43, 14:23, twice in 19:4), and with a noun in 3 instances (20:21, 24:24, 26:18). In Corpus Paulinum - 3 times with a verb (Rom 10:10.14, Phil 1:29) and 3 times with a noun (Rom 4:5.9; Eph 1:15). In 1 Pet 1:8, the form is present with a verb, and in Heb 10:39 with a noun. The es-

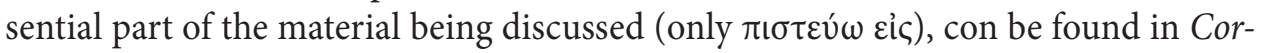
pus Johanneum (30 occurrences in John and 3 in 1 John). Outside Corpus Paulinum and Heb it is an expression concerning the faith in Jesus or else trusting Him or an object referring directly to Him (name, testimony or light). Also there, in Corpus Paulinum, occasionally we can observe a similar situation (Rom 10:14, Phil 1:29). In Rom 4:5.9 and Heb 10:39, the situation is different. First two texts (Rom 4:5.9) refer to Gen 15:6, just like the fragment from Philo's Quis rerum divinarum heres sit 1,94. In all three instances (Philo, Her. 1,94, Rom 4:5.9) appears the expression

44 An attempt of showing a broad panorama of the relations between the gnoseological terminology of Philo and Eph has been presented by Eberhardt Faust (cf. Pax Christi, 19-72). 


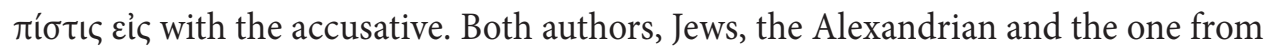
Asia Minor, employ the same linguistic form. However, there is an important distinction between the exegesis of Philo and the exegesis of Paul. Paul emphasises faith as the fundament of justification preceding the circumcision in the case of Abraham. In this way, he promotes a new economy of salvation, that surpasses the frames of Judaism significantly, by relativising circumcision as the border of the community of salvation. Preservation of the construct from the Septuagint in his case functions as a validation: a textual proof from Torah for the soteriology rejecting the criterium of ethnicity, referring to the Hellenistic cosmopolitism and individual search for the way of salvation. Paul aims to demonstrate his readers that he is a Jew, relying on his thinking on Torah, but not closing the economy of God's salvation to his own ethnical group. Moreover, he intends to persuade other Jews to accept this interpretation of the Torah, that he himself finds correct.

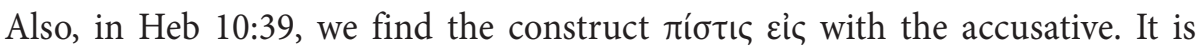
the second element of an incomplete, but clearly audible antithetical parallelism, in which نं consists in undertaking a spiritual effort and differs from the attitude of avoidance of difficulty. It is a development of Hab 2:4 but does not concern the expressions we are interested in. In fact, the consequences of two mentioned attitudes are introduced to the text by the author of Heb, from Hab he adopts only two opposing behaviours: faith and avoidance of difficulty.

In the context of the discussion on Eph 1:15, it is worth mentioning a passus from the Epistle to the Magnesians written by St. Ignatius of Antioch. ${ }^{45}$ Tenth paragraph

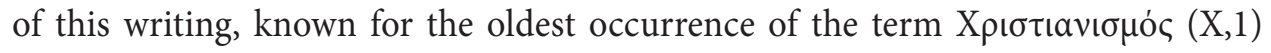
used in opposition to Iov反aï $\mu$ ó (first occurrence in 2 Macc 2:21), provide us with a fragment important for our discussion: ó $\gamma$ á $\rho$ X

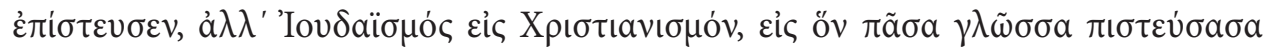

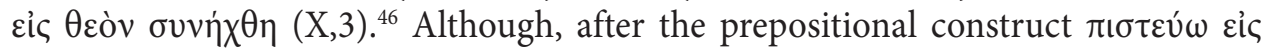
Ignatius employs a noun referring to a belief, an opinion concerning the mode of life

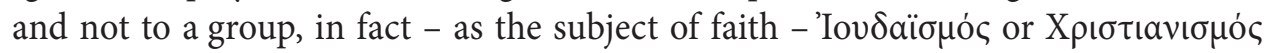
cannot be considered as abstracts but, precisely, social communities. Faith in them is

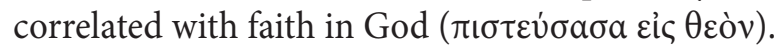

Bishop Ignatius of Antioch, who died in Rome around $140 \mathrm{CE}$, as it is supposed today, ${ }^{47}$ is the first witness of the conviction concerning Pauline authorship of Eph and the community in Ephesus as the destination of the letter. ${ }^{48}$

\footnotetext{
45 I owe my gratitude for this suggestion to prof. Daniel Boyarin from University of California, Berkeley.

46 Ignace - Polycarpe, Letters, 90.

47 Barnes, "The Date," 119-130; Pervo, The Making, 134-135.

48 In his commentary to the first editions of St. Ignatius' letters translation, Thomas Camelot wrote, that the answer to the question whether Eph is addressed to Christians in Ephesus cannot be deduced from Magn. XII,2 (Ignatius, Lettres, 55, n. 2). In the final edition from 1969, he elides this fragment.
} 


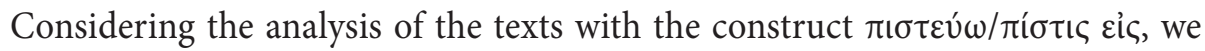
may say that Eph 1:15 belongs to the category of expressions indicating either the addressees or the objects of the activity. Thus, it is not a Semitism meaning 'to believe/ faith (in) someone' (dative) (characteristic above all to Corpus Johanneum), but rather 'believe for something/someone', or 'in someone's favour', 'because of someone's good/benefit'. Based on classical grammatical analysis it can be stated that in Eph 1:15

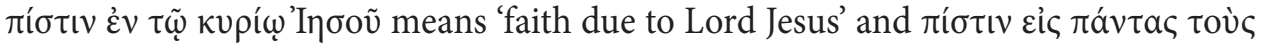
áyíous can be translated as 'faith because of all the saints'.

\section{The Saints in Eph}

Hence, the next step in the analysis of Eph 1:15-23 must consist in answering the question concerning 'the saints' (oi ä $\gamma$ เo ) from the verse discussed. The term is widely present in Eph: 15 occurrences. For comparison - it is absent in Gal, in Phil it is used 3 times, and in Col 6 times. The choice of those letters as a material for comparison is based on the criteria of volume and of appropriation of two of them to authentic (Gal, Phil) and two to discussed Pauline letters. Besides the frequency of occurrence, it is characteristic that in Eph the term is employed only 4 times in singular and 11 times in plural. In the first group, in two cases, the author speaks about the Holy Spirit $(1: 13,4: 30)$. Although in 2:21 and 5:27 the term in the singular is used, it refers to the Church, as it is also in 11 remaining instances (1:1.4.15.18, $2: 19,3: 5.8 .18,4: 12,5,3,6: 18$ ).

The more numerous group, with the adjective ä $\gamma$ เoৎ, is characterised by its oc-

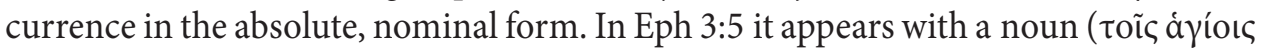

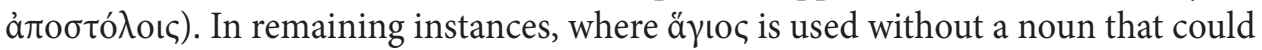
describe by this adjective, the term defines the community of believers, the Church of disciples of Christ, where He is the cornerstone and the Apostles are the foundation (Eph 2:20). For comparison, in Phil the adjective occurs in the absolute sense only in stricte epistolary parts - in the address (prescript, Phil 1:1) and in the ending (postscript, Phil 4:21.24). In Col it appears in the prescript (Col 1:2), the adjective is not present in the postscript, but is used 4 times in $\mathrm{Col} 1$ (Col 1:4.12.22.26) and once in the rest of the writing ( $\mathrm{Col} 3: 12)$. Every time it occurs in the plural and refers to Christians: the addresses $(1: 2.22,3: 12)$, other Christians loved by the addresses (1:4) or the whole Church community (1:12.26). The definition of Church community and local Churches as saints seems to be a common practice in Corpus Paulinum: both in the authentic letters and in the post-Pauline tradition. In Rom, the adjective is present 20 times in 19 verses. It describes the Holy Spirit 6 times (5:5, 9:1, 14:17, 15:13.16.19), 6 times it refers to the elements of the cultic and religious reality of Judaism: Scriptures (1:2), Law (7:12a) and commandment (7,12b), first fruit (11:16), 
sacrifice (12:1); or derived from Hellenistic style of life (kiss; Rom 16:16). About the saints as the members of the Church Rom speaks in 1:7, 8:27, 16:2.15 and specifically as members of the Church community in 12:3, 15:25.26.31. Hence, we can state that - comparing to Rom - in Eph, 'the saints' became a technical ecclesiological term. Moreover, the theme of the Jerusalem community, as a privileged one towards which Christians from the 'nations' have a debt of gratitude that should be paid off by the collection (Rom 15:26-27) has disappeared. The Church in Eph (and the same can be said concerning $\mathrm{Col}$ ) is a 'Church of saints' - more internally consolidated by spiritual elements, than by external forms of charity. The Judaistic realm of sacrum is not described in this Church.

Who are the saints in Eph? In 1:15 and 3:8.18, we read 'all the saints'. Byzantine type of the text contains this cluster of words also in Eph 1:1 (cf. 2 Cor 1:1, Phil 1:1). They are the main addresses of Eph. If we acknowledge that the insertion $\dot{\varepsilon} v^{\prime} \mathrm{E} \varphi \varepsilon \dot{\sigma} \sigma \omega$ in Eph 1:1 is late and secondary, being a saint is the only criterion of affiliation to the community of the addresses of this letter. It is not the only possible hypothesis, what can be seen from external evidence we have discussed elsewhere. ${ }^{49}$ We consider the question of the shorter ('To those who are saints and faithful due to Jesus Christ') or longer version ('To those who are saints and faithful in Ephesus due to Jesus Christ') of the text opened for discussion. The faith due to Jesus Christ (

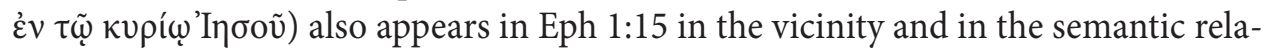
tion with the note concerning the saints, who - as we determined - have their share in the formation of faith of the community of addresses. All the saints, a community of believers broader than the local one, is the purpose of God's call addressed to the community. The author is identifying himself with this community with the use of first-person plural inclusive pronoun ( $\dot{\varepsilon} \xi \varepsilon \lambda \varepsilon_{\varepsilon} \xi \alpha \tau o$ in $\mu \tilde{\alpha} \varsigma$, Eph 1:4).

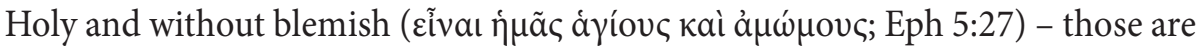
the characteristics of the Church. The term ä $\mu \omega \mu$ o offers an example of a successful substitution of a Hebrew word describing something complete, whole, without any deficiency (תִָָּ ) by a Greek term meaning something without stain, flaw, defect, that refers to the Temple cult, especially sacrificial animals. It is an interesting example of the Hellenization of the language of Torah in the Septuagint. The meaning has been adopted by Christian milieu in the Christological sense (Christ as a sacrifice holy and without blemish; Heb 9:14, 1 Pet 1:19), in the soteriological sense (Christ's sacrifice sanctifies those who believe in Him and makes them without defect, thus disqualifying the sacrificial animal; Col 1:22, cf. Rev 14:4-5), and in the ecclesiological sense (Church as a community characterised by holiness and without blemish; Phil 2:15, Jude 1:24, Eph 1:4, 5:27). Phil 2:15, where Christians are depicted as the perfect people of God, sons of God, separated in the religious and moral sense from the unclean nation, is the oldest and undoubtedly Pauline amongst those texts. The hope of in-

Cf. Linke, “Uwierzyć”" 139-155. 
heritance among the saints (cf. Eph 1:18) can be realised only outside the earthly horizon. This eschatological inheritance derives its character from the riches of

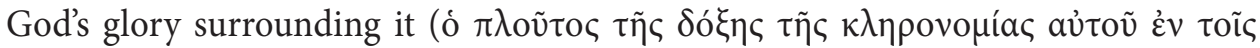
áyíoı). Glory is rooted in God Himself, who is the Father of glory (1:17). Glory is also the measure of God's actions for human good (3:16). Hope, accomplished and mediated by Christ, is connected with the possibility of directing human existence to the immensity of God's glory (1:12). This immensity is the foretaste, literally a pledge

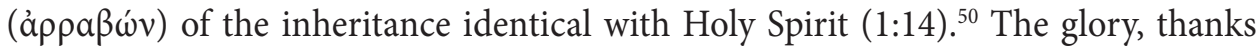

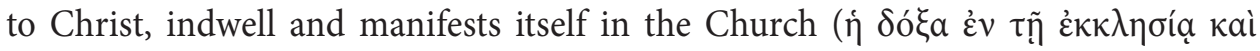

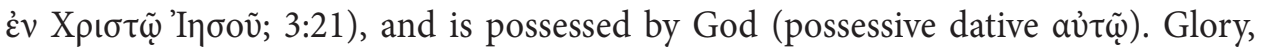
coming from God and realised by Jesus Christ and by Holy Spirit, remains in rela-

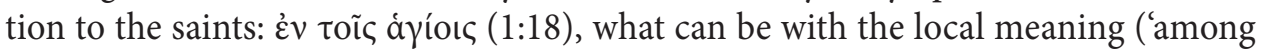
the saints') or causally/instrumentally ('because of the saints' or 'due to the saints'). Hence, it is not an earthly emanation of God's presence, but rather a mode of His existence in a different realm and a manifestation in the world through the saints. In this sense, glory is an eschatological element. The saints are building the body of Christ through cleansing themselves (Eph 4:12).

The saints also form $\dot{\eta} \pi$ ó $\lambda ı$, in which they are $\sigma 0 \mu \pi 0 \lambda \tilde{i} \tau a$. The latter remains

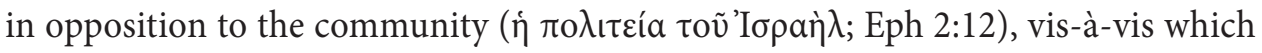
they were outsiders ( $\xi \dot{\varepsilon} v o l$, vv. 12 and 19). This rare word in the Greek Bible occurs only in Eph 2:12 and Acts 22:28. Whereas its reference to the legal situation of characters arguing in the latter text is not unexpected, the description of Israel community with this term astonishes the reader. Well-known commentator of Eph asserts that this term: "In the first century AD, [...] would refer to a group of people bound together by their ethnicity [...], their belief in one God, their commitment to living under the governance of the Torah, and their status as being God's elect." ${ }^{51}$ He failed, however, to demonstrate to which subject ( fers. This term occurs in the Greek Bible only in Phil 3:20, where the author speaks about a collective political being situated in Heaven, to which Christians belong. The juxtaposition of this type of relation, understandable only through a reference to Hellenistic language of politics ${ }^{52}$, with a covenant in the religious sense, distinctive for the theology of Judaism, amazes, and even shocks. It becomes comprehensible only in the light of a religious perspective of Jerusalem of the Herodian period, as the centre influencing every place, where are to be found people professing God worshipped with Jerusalem's Temple offerings and guided by the rules founded on Torah on a daily basis.

\footnotetext{
50 Allen, Ephesians, 21-22; Bock, Ephesians, 45-46.

51 Arnold, Ephesians, 155. Cfr. Best, Ephesians, 241-243.

52 Shipley - Hansen, "The polis", 52-72.
} 
'The saints' in Eph are an ecclesiological and eschatological category, not a political one. Carey C. Newman pointed out that the function of the apocalyptic motif of resurrection in Eph is to disclose the theological sense of the narration concerning the cross. "Without resurrection's apocalyptic intrusion, the death of Jesus would be trivial-if not an outright empty, black hole of tragic history." ${ }^{53}$ This element of eschatology is perceivable as well in the image of the Church that we know from Eph. It is firmly grounded in the Judaistic theological context, though presented in terms based on the experience of a society of a different type than the theocratic one (Eph 2:14-15). The latter, from the Jewish perspective, was ruled by a religious apparatus connected with the Temple and constitutes a community not only of those who dwell in the city of Jerusalem but of all those for whom this place of worship was a point of reference. Nevertheless, in Eph, it is not the 'administrative centre', nor the boule of Jerusalem, that constitutes the point of reference. It is the social community bound together by the fact and the consciousness of belonging to a religious community of the saints. This social community is substantial for the celebration of God's power not only in the Temple and in the peculiar institutions of Judaism, but in the universal dimension as well (Eph 2:19-20; 3:17-19).

Hence, the affiliation to the community of the saints by the covenant constitutes a topos of Helleno-Judaistic literature of the Roman period. Along with the conviction that it is a mission directed not only to Israel - despite its distinctive role regarding the nations, due to its position towards God that is based on the covenant. From this perspective, the position of the 'saints', or the people of God, is exceptional also because of its specific role - a medium of transmitting the knowledge about God's salvation plan towards all humanity. Faith because of all saints, that Eph 1:15 speaks about, is fully understandable in this context. It points out rather to the Hellenised Judeo-Christians than to the community of Jerusalem.

The saints in Eph 1:15-23 differ from the group addressed by the author with the $2^{\text {nd }}$ person plural pronoun. This fact contrasts this pericope with Eph 1:3-12, where the author identifies himself with the group of the addressees described as 'we, ${ }^{54}$ which has an explicitly Judeo-Christian identity (Eph 1:12). ${ }^{55} 1: 13-14$ introduces 'you (pl.)' that describes the ones 'sealed' with the Holy Spirit, thus sanctified, marked with holiness and possessing the pledge of the salvation expressed with a language of promise and heritage. This group is characterised by the spirit of wis-

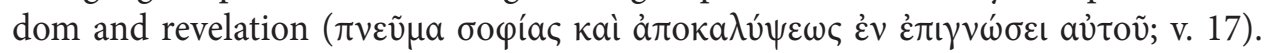

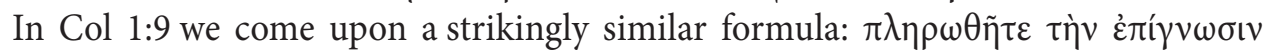

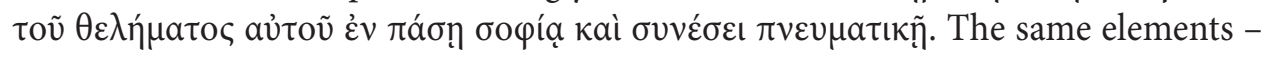

53 Newman, "Narrative," 322-337, esp. 336.

54 Lionel J. Windsor ("The Formation," 382) points out to the division on 'we' and 'they' in the Epistle of Barnabas, in which 'they' are the Jews. It is an important indicator of different approaches. For this approach, he finds as equivalent in Eph 2:17, though he sends back to Isa 57:19 (ibid., 383). 


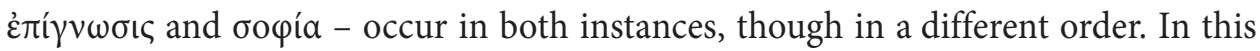
context, it is important to ask two questions. First are the spirit of wisdom and Holy

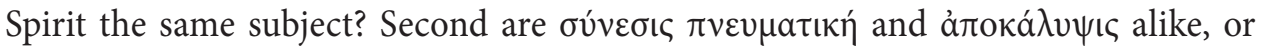
complementary? The first question seems to be simpler. Chantal Reynier presented persuasive reasoning that allows equating those two expressions based on Hebrew Bible text (Deut 34:9). ${ }^{56}$ Avoiding any closure does not add up anything to the understanding of the text, eventually, even this approach must lead to a decision in favor of one among the options. Barth ${ }^{57}$ opts for an anthropological interpretation. Paradoxically, this interpretation emphasises God as the giver of wisdom and revelation even more. Concerning the second question, Rudolf Schnackenburg deemed spiritual understanding and revelation as equal. ${ }^{58}$ Stephen E. Fowl deduces that "combination of 'wisdom and revelation' in 1:17 helps to explicate the notion of 'knowledge' of God, which Paul prays will be the result of the Spirit work." ${ }^{99}$ Both human cognitive act and given revelation are summarised in the image of the eyes of a heart capa-

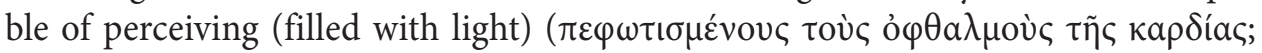
Eph 1:18). Frank Thielman considers it a metaphor present in both Greco-Roman and Judaistic literature. ${ }^{60}$ However, the material quoted by this scholar (Ovid, Metam. 15,6061. Corpus hermeticum 4,11b, cf. 7,1a, and 1QS 2,2-3) consists rather of a set of examples from two different cultural sources, a depiction of the creation of a characteristic amalgamate of motifs from different cultural traditions in late Hellenistic period. With reference to the Community Rule, Ehrhard Kamlah wrote that in 1QS 3:15-4:26 the creed in creation, typical for Judaism, is confronted with a Greek image of the world. This contrast voiced itself in the tension between what is, and what is to come. ${ }^{62}$

On the basis on this and similar observations, Martin Hengel builds up his thesis: already in the Maccabean period ( $2^{\text {nd }}$ century BCE) every form of Judaism, including Palestinian one, was Hellenistic. ${ }^{63}$ As a distinctive trait of Essenic doctrine, he considered the intellectualization of piety. This process leads wisdom and apocalyptic, revelatory trend in Judaism to an extremum, introduced the terminology of knowledge, cognition and mystery, as far as to the formation of the concept of the 'salvatory knowledge. ${ }^{64}$ Here, this language is not marked yet with the idea of self-salvation, that will determine the borderline of gnosis, in which man acquires salvatory knowl-

\footnotetext{
56 Reynier, Lépître, 74. A broader explanation in: Hoehner, Ephesians, 256-258.

57 E.g., Barth, Ephesians 1-3, 148.

58 Schnackenburg, The Epistle, 74.

59 Fowl, Ephesians, 56.

60 Thielman, Ephesians, 98.

61 Strecker - Schnelle, Neuer Wettstein, 596.

62 Kamlah, Die Form, 44, n. 1.

63 Hengel, Judentum, 444-445.

64 Hengel, Judentum, 466.
} 
edge. In this case, we deal with its revelatory character and God as the source of knowledge. The language of cognition is employed in the process of faith transmission in soteriological religion, in order to express the need for human engagement in accepting God's gift of salvation. In this way, the salvation that originated from Jews became an element of human development, self-improvement - this happened, however, in a manner in which gaining soteriological knowledge did not substitute God's acts. Man did, nonetheless, discover in salvation a humanistic horizon, thanks to which knowledge became a way of accepting the gift of salvation. In the cultural perspective, we can speak about a fusion of languages, that allowed a new expression of religious content, what gave rise to its communication in a new social perspective. The ecclesiological character of Eph, in opposition to gnostic interpretations, was demonstrated by Helmut Merklein in his dissertation written under the supervision of Rudolf Schnackenburg. We share Merklein statements and argumentation. ${ }^{65}$

In Eph 1:3-14 eulogia, cognition and knowledge as soteriological elements frequently appear, though not from the very beginning of the pericope. This God worshipping prayer has for its fundament God's action. Author's own community

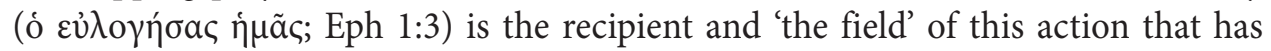
three characteristics introduced by $\dot{\varepsilon} v$. Two of them, as mentioned above, describe

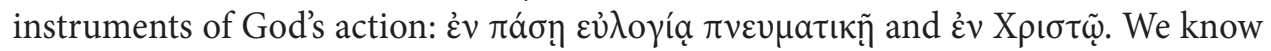
already this scheme of God's, Christ's and Holy Spirit's action, in which Spirit and Christ are two hands of God, as St. Irenaeus of Lyon wrote (cf. Adv. Haer. 5,6,1) ${ }^{66}$

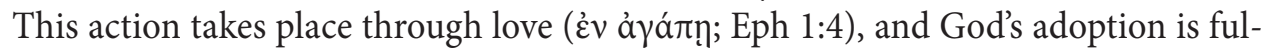

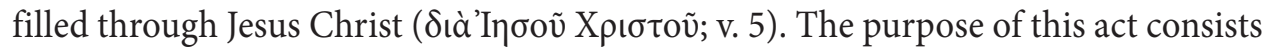
in praise of riches of God's grace that He bestows upon 'us' - in other words, the community of the narrator of the letter - through Beloved Son (Eph 1:6). It is accomplished in a form illustrated by two pictures: redemption (

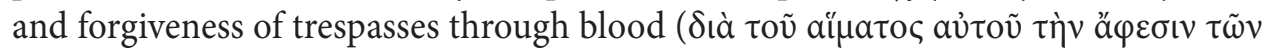
$\pi \alpha \rho \alpha \pi \tau \omega \mu a ́ \tau \omega \nu ;$ v. 7).

Salvation is made available to the group 'we' (v. 8-9) through the knowledge of

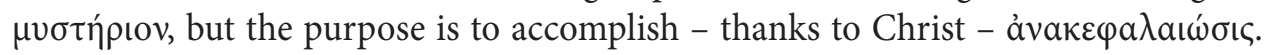
This noun is not present in the Greek Bible, though in Rom 13:9 and Eph 1:10 oc-

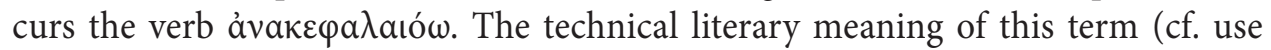
of the noun by Dionysius of Halicarnassus, Ant. Rom. 1,90, in the meaning of summarising a larger narration) does not seem to have any application here. The meaning interesting for us is based on the relation between, on the one hand, the work of Jesus, through which comes the eschatological order of the fullness of times (oikovouía tov

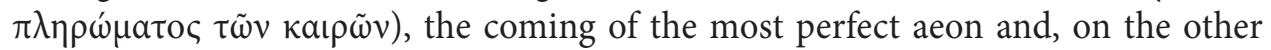

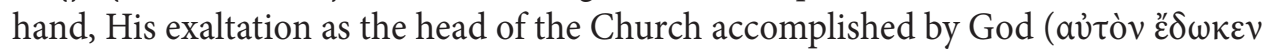

65 Merklein, Das kirchliche, 48-58.

66 Irenaeus, Adversus Haereses (Brylowski, 439). 


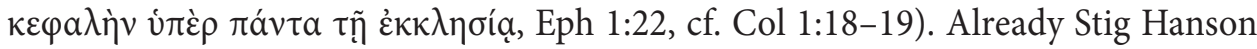

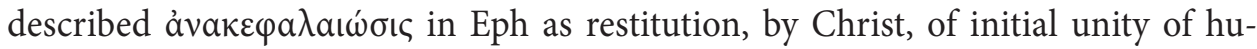
manity divided by differences of technical and religious status. ${ }^{67}$ The inclusion of believers to this organic community, with Christ as its head, can be realised through the transfer of the revelation. Hence, the intellectual knowledge (extra-sensuous as in a vision - cognition) is the vehicle of revelation and the beginning of salvation, that is fulfilled in existence for the immensity of God's glory, what is explicitly stressed (Eph 1:11-12.14). The role of Eph 1:13 is merely to introduce the group 'you (pl.)', in order to show the diversity of ways and the unity of the objective.

The manifestation of salvation that the author speaks about in Eph 1:9, effectuates through the knowledge of mystery ( $\left.\mu v \sigma \tau \eta \dot{p} \rho{ }^{\circ} v\right)$ of God. This mystery functions on two grounds: on the one hand, it was purposed in the past through the mediation or with the contribution of Christ, on the other hand, the group 'we' came to know it thanks to grace lavished upon this group (v. 8) and Christ's blood (v. 7). Thus, 'we' is presented as a group that experienced the results of salvatory death of Christ before. The moment of knowing the mystery of God's will is important to such an extent, that post-Pauline author of Eph recurs to it in Eph 3:3: кatà ảं

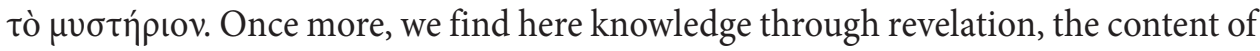
which is the mystery. Thus, this situation is equal to the one from Eph 1:7-9. There-

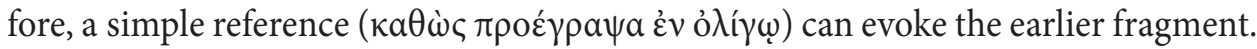
The change of subjects in 3:3 - the introduction of a literary character of Paul as a privileged recipient of the revelation - is important. It refers to the definition of mystery in Eph 1:3-14. The revelation has been given first of all to the prophets and the apostles (Eph 3:5). For Paul, it is a legitimization of belongingness to the group of those, to whom God reveals His plans. On his part, Paul from Eph proclaims to the gentile part of the community (pl. 'you'), but he himself belongs to the saints, even if he is the very last of them (Eph 3:8). The content of this mystery consists in the community of evangelised gentiles and the saints, in other words, community of participation in the body, which does not need to be called here (Eph 3:6) the body of Christ ${ }^{68}$, as it has been described this way in Eph 1:22-23. The author of Eph makes a reference to Paul's knowledge of God's mystery and his role of the intermediary in its transmission to the community 'you' (pl.). It seems even more important to make this community aware of the fact, that the author, speaking in the voice of imprisoned

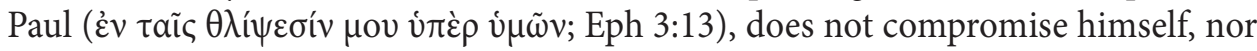
his mission. On the contrary, in this way, he realises the glory of the group 'you' (pl.), the glory of the recipients of his mission. It is a situation only superficially similar to the one described by Paul of Tarsus in Phil 1:12-26. In Phil, the context consists in the tensions concerning a power struggle within the Church, whereas Paul empha-

67 Hanson, The Unity, 123-126.

68 Cohick, The Letter to the Ephesians, 135-136; Baugh, Ephesians, 129-131. 
sises the issue of personal existential choice: to demand from oneself further efforts or give in to the weariness and accept the condition of his exhaustion. Those personal and background elements are lacking in Eph, where the situation is built upon clear divisions, but not upon conflicts. The situation is formed by model groups and language categories, not real individuals and groups. It is important, however, to retain in this category of the addresses of the mission of literary Paul from Eph, a proper understanding of salvation based at times on the testimony through steadfastness in suffering and facing trial - a tribulation.

It is worth asking a question concerning the type of soteriology that we encounter in Eph 1:22-23, where the author speaks in the voice of Paul, a Pharisee from diaspora in Asia Minor. Salvation is carried out here in a manner quite distant from the one that presented pagan soteriological cults, where the emphasis was on human well-being. Connection of gods' beneficence ( of soteriological functions to rulers titled $\sigma \omega \tau \eta \dot{\eta} \rho$, presents a very particular character of the salvation. In 290 or 291 BCE, the Athenians prayed to Demetrius I Poliorcetes: "For other gods are either far away, or they do not have ears, or they do not exist or do not take any notice of us, but you we can see present here, not made of wood or stone, but real." ${ }^{69}$ This concept of deity is stressed by Angelos Chaniotis: presence, effica$c y$, affability.$^{70}$ Already William Tarn wrote concerning the cult of Hellenistic rulers: 'This is why man approved a cult of the king: cultic nicknames of previous kings Soter (Saviour), Euergetes (Benefactor) - are an expression of the fact that they were worshipped due to their doings. ${ }^{71}$ Although Frank W. Walbank emphasised rather 'personal contact with the deity' or 'life after death' as key elements of Hellenistic soteriological cults, ${ }^{72}$ the particular benefit of religious practices and theological attitude has an important meaning. If stoics saw body even in good and were interested in it as long as it presented bodily implications good for the body (Seneca, Letters 106,3), it is not surprising, that also salvation was interpreted in a very practical manner. Ewa Wipszycka observes, that a manifestation of deity - an epiphany - was not so much an appearance of the deity in a visible form as a manifestation of its philanthropy through 'miraculous interventions. ${ }^{73}$ A soteriological vision, in which the elimination of personal sin comes to the fore instead of the improvement of a medical condition, financial standing or the security level, is the attitude that contrasts with Hellenistic soteriology. The character of salvation in late Judaism and Christianity is not so utilitarian and material. It is well illustrated by the development of a theology of martyrdom in Judaism and (especially) in Christianity. Until (and including) the time of Maccabean crisis, in biblical narrations concerning religious

69 Chaniotis, "The Divinity," 431.

70 Chaniotis, “The Ithyphallic," 160.

71 Tarn, Cywilizacja hellenistyczna, 87.

72 Walbank, Świat hellenistyczny, 219.

73 Bravo - Wipszycka, Historia starożytnych, 497. 
persecutions prevailed a vision of salvation based on God's redemptive intervention of the persecuted individual or group. ${ }^{74}$ Maccabean literature changes this perspective radically: 'Only exceptionally a disgracing execution could have been a factor for the heroization amongst the Greeks [...] only in cases when a miraculous intervention of gods prevented the process of decomposition [...]. In Jewish stories, on the contrary, it was not about avoiding the disgrace, but about the transition to another life. ${ }^{75}$ The eschatologization of soteriology became the axis of this shift, by which not the worldly benefit was regarded as the revelation of God's power, but rather the testimony of human faith in the capability God, who created the world, to a new creation that will restore in a more perfect form (in a better aeon) this, what

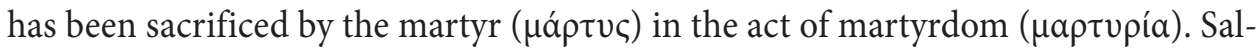

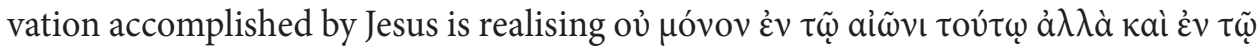

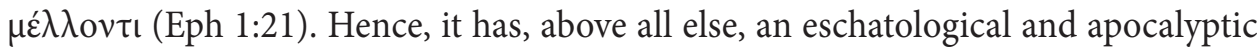
dimension. It has for its foundations God's action and, also, the reception (faith) of the individual and of the social community. This attitude has a revelatory (apocalyptic) genesis. The understanding of salvation in Eph is, therefore, consistent with the trend that was developed in Hellenistic Judaism since late Maccabean times. ${ }^{76}$ The only novelty in Eph, though a significant one, consists in the association of salvation with the necessity of Jesus Christ's mediation and the Holy Spirit's action.

In Eph 1:15-23, the language of cognition and knowledge is not represented as extensively as in 1:3-14. As we have mentioned above, it is concentrated in v. 18 and the following. But with the end of Eph 1:19, the sentence is not finished, as 1:20 begins with a relative pronoun relating logically to the ending of 1:19. The exaltation of Christ is portrayed in a manner characteristic of early Christology - on the basis of Ps 110,1. ${ }^{77}$ The revelation of the exalted Jesus was accomplished for the group 'you' (pl.) through the mediation of the 'saints', the group 'we', to which epistolary Paul belongs. The beginning of a new component part can appear only in 1:22. Eph 1:22-23 is, therefore, descriptive and refers to the glory of exalted Jesus, just like in Phil 2:9-10. An important characteristic of Eph 1:22-23, and the one that cannot be erased, is the emphasis on the somatic unity of the Church: 'we', 'you' (pl.) and the Head - Christ. Due to Christ, those who receive the message of the Gospel from the apostles (from Paul) are called to equal participation in the community of the saints (Eph 1:18) and obtain this participation by accepting the role and ministry of the saints (of Paul). Hence, faith because of all saints plays in Eph 1:15 an essential role in the understanding of Eph 1:15-23 and the whole letter. They appear as

74 Linke, "Od skandalu," 12-39.

75 Baslez, Prześladowania, 168 [own translation].

76 The composition of 2 Macc is dated between 124 and 63 BCE. Cf. Laskowski, Druga Ksiega Machabejska, 92.

77 Linke, "Eschatologiczny," 165-186, esp. 174-184. 
the agents of the mission of breaking down the ethnical barriers, what has as its beginning and ả $\rho \chi \eta ́$ what Jesus accomplished on the cross. ${ }^{78}$

\section{Conclusions}

The analysis of the shorter version of Eph 1:15 helped us with a better understanding of the role of the 'saints' of the Church, and thus the witnesses of the continuity of God's plan. They do not constitute a closed religious social community holding a set of special rights, that can be enforced in the form of consensual taxation of other communities on its behalf. In Eph, Paul is considered to be a representative of the 'saints', if not even as their model. On the other hand, the unity of the Church, that implies the incorporation of the group 'you' (pl.) to the saints, constitutes the message of the good news proclaimed by him.

Language and forms of proclaiming this good news belong essentially to Hellenised Judaism. We have demonstrated it with the comparison of the epistolary form of 2 Macc 1:18-36 and Eph 1:3-23 and with the exegetical study of the principal theological ideas essential for the understanding of Eph 1:15-23. On this basis, we can conclude that it is precisely Hellenised Judaism that constitutes a field of research crucial for a correct understanding of the early Christian message. In other words, after a period of appreciation of Hebrew Bible, synagogue, Targum and Talmud as the main point of reference for the study of the origins of Christianity, it is time to give preference to Septuagint and the milieu of its redaction. It does not imply any withdrawal from the interest with Hebrew and Aramaic scripture exegesis but encourages scholars to see also in those texts a Judaism formed and influenced by the Hellenistic period.

Surely, the author of Eph could not consider the words of John Chrysostom drawing a firm borderline between Jewish and Christian politeuma to be his own:

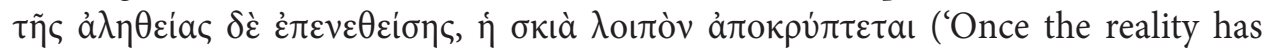
come, the type which foreshadowed desapears', Adv. Jud. 3,4). From the perspective of Eph, it is difficult to draw such a borderline, because terminology elaborated by Hellenised Judaism provided the ways of proclaiming Jesus Christ, and $\mathrm{He}$ and His saving work are presented as the fullness of the mystery of God's will, that are to be revealed and honored (Tob 12:7).

Translated by Mateusz A. Krawczyk

Baulès, L'insondable richesse, 31-36. 


\section{Bibliography}

Allen, M., Ephesians (Grand Rapids, MI: Brazos Press 2020).

Arnold, C.E., Ephesians (Exegetical Commentary on the New Testament 10; Grand Rapids, MI: Zondervan 2010).

Arzt-Grabner, P., "Paul's Letter Thanksgiving," Paul and the Ancient Letter Form (eds. S.E. Porter - S.A. Adams) (Pauline Studies 6; Leiden - Boston, MA: Brill 2010) 129-158.

Barnes, T.D., “The Date of Ignatius," The Expository Times 120/3 (2008) 119-130.

Barr, J., The Semantics of Biblical Language (London: Oxford University Press 1961). Italian trans. P. Sacchi: Semantica del linguaggio biblico (Bologna: Edizioni Dehoniane Bologna 1980).

Barth, M., Ephesians 1-3 (Anchor Bible 34; London: Yale Univeristy Press 1974).

Baslez, M.-F., Prześladowania w starożytności. Ofiary, bohaterowie, męczennicy (trans. E. Łukaszyk) (Kraków: WAM 2009).

Baugh, S.M., Ephesians (Bellingham, WA: Lexham Press 2016).

Baulès, R., L'insondable richesse du Christ. Étude des themes de l'Épittre aux Éphésiens (Lectio Divina 66; Paris: Cerf 1971).

Bengel, J.A., Gnomon Novi Testamenti, 3 ed. (Londuni - Edimburgi: Williams \& Norgate 1862; 1 ed., 1742).

Best, E., Ephesians (Edinburgh: Clark 1998).

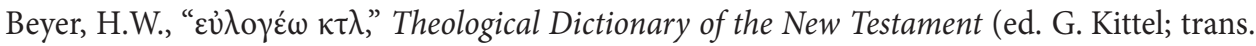
G.W. Bromiley) (Grand Rapids, MI: Eerdmans 1964) II, 754-765.

Blass, F. - Debrunner, A., Grammatica del greco del Nuovo Testamento (Supplementi al Grande lessico del Nuovo Testamento 3; Brescia: Paideia 1982).

Bock, D.L., Ephesians (Downers Grove, IL: InterVarsity 2019).

Bravo, B. - Wipszycka, E., Historia starożytnych Greków. III. Okres hellenistyczny (Warszawa: Wydawnictwo Naukowe PWN 1992).

Bruce, F.F., The Epistles to the Colossians, to Philemon and to the Ephesians (Grand Rapids, MI: Eerdmans 1984).

Bultmann, R. - Weiser, A., “ $\pi\lrcorner \sigma \tau \varepsilon \dot{\omega} \omega \tau \tau \lambda$," Theological Dictionary of the New Testament (ed. G. Kittel; trans. G.W. Bromiley) (Grand Rapids, MI: Eerdmans 1969) VI, 174-228.

Chaniotis, A., "The Divinity of Hellenistic Rulers," A Companion to the Hellenistic World, (ed. A. Erskine) (Malden, MA - Oxford: Blackwell Publishing 2003) 431-445.

Chaniotis, A., "The Ithyphallic Hymn for Demetrios Poliorcetes and Hellenistic Religious Mentality," More than Men, Less than Gods. Studies in Royal Cult and Imperial Worship. Proceedings of the International Colloquium Organized by the Belgian School at Athens (November 1-2, 2007) (eds. P.P. Iossif - A.S. Chankowski - C.C. Lorber) (Leuven: Peeters 2011) 157-195.

Cohick, L.H., The Letter to the Ephesians (Grand Rapids, MI: Eerdmans 2020).

Dunning, B.H., "Strangers and Aliens No Longer: Negotiating Identity and Difference in Ephesians 2," Harvard Theological Review 99/1 (2006) 1-16.

Faust, E., Pax Christi et Pax Caesaris. Religionsgeschichtliche, traditionsgeschichtlische und sozialgeschichtliche Studien zum Epheserbrief (Novum Testamentum et Orbis Antiquus 24; Freiburg: Universität Freiburg Schweiz 1993). 


\section{WALDEMAR LINKE}

Fowl, S.E., Ephesians. A Commentary (Louisville, KY: Westminster John Knox 2012).

Gryglewicz, F., Księgi Machabejskie. Wstęp, przekład z oryginału, komentarz (Pismo Święte Starego Testamentu 6/4; Poznań: Pallotinum 1961).

Hanson, S., The Unity of the Church in the New Testament (Acta Seminarii Neotestamentici Upsaliensis 14; Uppsala: Almquist \& Wiksells 1946).

Hengel, M., Judentum und Hellenismus. Studien zu ihrer Begegnung unter besonderer Berücksichtigung Palästinas bis zur Mitte des 2. Jahrhunderts vor Christus, 3 ed. (Tübingen: Mohr [Siebeck] 1988; 1 ed. 1973). Italian trans. S. Monaco: Giudaismo ed ellenismo. Studi sul loro incontro, con particolare riguardo per la Palestina fino alla metà del II secolo a.C. (Brescia: Paideia 2001).

Hoehner, H.W., Ephesians. An Exegetical Commentary (Grand Rapids, MI: Baker Academic 2002).

Ignace d'Antioche, Polycarpe de Smyrne, Letters. Martyre de Polycarpe (ed. P.-T. Camelot) (Sources chrétiennes 10; Paris: Cerf 1969).

Ignatius, Lettres (ed. P.-T. Camelot) (Paris: Cerf 1944).

Irenaeus, Adversus Haereses, trans. J. Brylowski: Ireneusz z Lyonu, Adversus Haereses (ed. J. Brylowski) (Pelplin: Bernardinum 2018).

Kamlah, E., Die Form der katalogischen Paränese im Neuen Testament (Wissenschaftliche Untersuchungen zum Neuen Testament 7; Tübingen: Mohr [Siebeck] 1964).

Käsemann, E., "Epheserbrief," Religion in Geschichte und Gegenwart (Tübingen: Mohr Siebeck 1958) II, 517-520.

Laskowski, Ł., Druga Księga Machabejska (Nowy Komentarz Biblijny. Stary Testament 14/3; Częstochowa: Święty Paweł 2017).

Lincoln, A.T., Ephesians (Word Biblical Commentary 42; Nashville, TN: Nelson 1990).

Linke, W., "Ef 1,15: tekst krótki czy długi?", Seminare 41/3 (2020) 11-23.

Linke, W., "Eschatologiczny wątek w procesie Jezusa przed Sanhedrynem (Mk 14,55-64). Mk jako pierwsza interpretacja eschatologiczna męki i śmierci Jezusa," Studia nad Ewangelia według św. Marka. Nowy Testament: geneza - interpretacja - aktualizacja (eds. J. Kręcidło - W. Linke) (Lingua Sacra Monografie 8; Warszawa: Bractwo Słowa Bożego - Ząbki: Apostolicum 2017) 165-186.

Linke, W., Literacka ojczyzna Tobiasza. Tło kulturowe Tb jako klucz teologicznej lektury ksiegi (Lingua Sacra. Monografie 2; Warszawa: Verbinum 2013).

Linke, W., "Od skandalu niewinnego cierpienia do teologii męczeństwa. Męczennicy w okresie Drugiej Świątyni," Słowo Krzyża 4 (2010) 12-39.

Linke, W., "Uwierzyć w Chrystusie (Ef 1,13.15)? Jezus Chrystus a wiara Kościoła w Ef," Warszawskie Studia Teologiczne 28/4 (2015) 139-155.

Maurer, C., "Der Hymnus von Epheser 1 als Schlüssel zum ganzen Brief," Evangelische Theologie 11 (1951-1952) 151-172.

Mazur, R., La retorica della Lettera agli Efesini (Milano: Terra Santa - Jerusalem: Franciscan Printing Press 2010).

Merklein, H., Das kirchliche Amt nach dem Epheserbrief (München: Kösel 1973).

Mussner, F., Der Brief an die Epheser (Ökumenischer Taschenbuch-Kommentar zum Neuen Testament 10; Würzburg: Echter 1982). 
Newman, C.C., "Narrative Apocalyptic in Ephesians," Perspectives in Religious Studies 44 (2017) 322-337.

O’Brien, P., The Letter to the Ephesians (Grand Rapids, MI: Eerdmans - Leicester: Apollos 1999).

Pervo, R.I., The Making of Paul. Construction of the Apostle in Early Christianity (Minneapolis, MN: Fortress 2010).

Philo, Philo with an English Translation (trans. F.H. Colson - G.H. Whitaker) (Loeb Classical Library 261; Cambridge: Harvard University Press - London: Heinemann 1985) IV.

Reynier, C., Lépître aux Éphésiens (Commentaire biblique. Nouveau Testament 10; Paris: Cerf 2004).

Reynier, C., Évangile et Mystère. Les enjeux théologique de L'Épître aux Éphésiens (Lectio Divina 149; Paris: Cerf 1992).

Schnackenburg, R., Der Brief an die Epheser (Evangelisch-katolischer Kommentar zum Neuen Testament 10; Zürich: Benziger 1982). English trans. H. Heron: The Epistle to the Ephesians. A Commentary (Edinburgh: Clark 1991).

Shipley, D.G.J. - Hansen, M.H., "The polis and Federalism," The Cambridge Companion to the Hellenistic World (ed. G.R. Bugh) (Cambridge: Cambridge University Press 2006) $52-72$.

Shkul, M., Reading Ephesians. Exploring Social Entrpreneurship in the Text (London: Clark 2009).

Stauffer, E., "Eic," Theological Dictionary of the New Testament (ed. G. Kittel, trans. G.W. Bromiley) (Grand Rapids, MI: Eerdmans 1965) II, 420-442.

Strecker, G. - Schnelle, U. (eds.), Neuer Wettstein. Texte zum Neuen Testament aus Griechentum und Hellenismus. II/1. Texte zur Briefliteratur und zur Johannesapokalypse (Berlin: De Gruyter 1996).

Talbert, C.H., Ephesians and Colossians (Paideia. Commentaries on the New Testament; Grand Rapids, MI: Baker Academic 2007).

Tarn, W., Cywilizacja hellenistyczna (trans. C. Kunderewicz) (Warszawa: Państwowe Wydawnictwo Naukowe 1957).

Theobald, M., "La Lettera agli Efesini," Introduzione al Nuovo Testamento (eds. M. Ebner S. Schriber; trans. Gianni Poletti) (Brescia: Queriniana 2012) 507-527.

Thielman, F., Ephesians (Grand Rapids, MI: Baker Academic 2010).

Walbank, F.W., Świat hellenistyczny (trans. Grzegorz Muszyński) (Warszawa: Pruszyński i S-ka 2003).

Windsor, L.J., "The Formation of Gentile Christ-Believing Identity vis-à-vis Israel in Epheesians and Barnabas," Biblica et Patristica Thorunienisa 11/4 (2018) 377-390. 
